\title{
Nilai Filosofis Bangunan Perpustakaan Ditinjau dari Pemikiran Arsitektur Posmodern
}

\author{
Rahmat Iswanto ${ }^{1}$, Hasni Hartati ${ }^{2}$ \\ Institut Agama Islam Negeri (IAIN) Curup \\ 1e-mail: rahmatiswanto.database@gmail.com \\ ${ }^{2}$ e-mail: hasnihartati040682@gmail.com
}

\begin{abstract}
This Article about the philosophical value of library buildings in terms of postmodern architectural thought is intended to answer the question of how important principles and values in a building are in the view of postmodern architectural experts, how the development of library buildings in Indonesia in particular. This paper is carried out by analyzing the philosophical values of postmodern architectural experts from various secondary sources. Important principles in preparing the building of a library can be adopted by digging information related to the science of architecture and experts. The expected benefits of this paper are important and aspirational information for research librarians and library workers to produce a further study related to the library building.
\end{abstract}

Key Words: Library Building; Library Architecture; Postmodern Architecture

\begin{abstract}
Abstrak
Tulisan tentang nilai filosofis bangunan perpustakaan ditinjau dari pemikiran arsitektur posmodern ini dimaksudkan untuk menjawab pertanyaan bagaimana prinsip dan nilai penting dalam sebuah bangunan menurut pandangan ahli arsitektur postmodern, bagaimana perkembangan pembangunan gedung perpustakaan di Indonesia khususnya. Tulisan ini dilakukan dengan menganalisis nilai-nilai filosofis ahli arsitektur postmodern dari berbagai sumber sekunder. Prinsip-prinsip penting dalam mempersiapkan bangunan sebuah perpustakaan dapat diadopsi dengan menggali informasi berkaitan dengan ilmu arsitektur dan para ahlinya. Manfaat yang diharapkan dari tulisan ini adalah sebagai informasi penting dan aspiratif bagi pustakawan dan ahli kepustakawanan untuk menghasilkan sebuah kajian lebih jauh berkaitan dengan gedung perpustakaan.
\end{abstract}

Kata Kunci : Gedung Perpustakaan; Arsitektur Perpustakaan; Arsitektur Posmodern 


\section{A. PENDAHULUAN}

Hingga abad ke sembilan belas, arsitektur dimaksudkan sebagai seni bangunan. Setidaknya dengan hadirnya arsitektur modern terjadi perubahan konsep tentang arsitektur. Terjadinya perubahan konsep ini dimulai pada abad ke delapan belas yangmana maksud arsitektur bukan dalam bentuk karya-karyanya melainkan dari segi gagasan, ide, pengetahuan dasar atau pemikiran dasar mengenai arsitektur. Penerapan dan menggunaan konsep tersebut baru dapat digunakan pertengahan abad ke sembilan belas. Hal tersebut karena pendidikan mengenai arsitektur dibedakan antara arsitektur sebagai seni dan arsitektur sebagai ilmu teknik sipil, sehingga muncul perindustrian atau produk bahan bangunan.

Perpustakaan sebagai suatu lembaga yang menjalankan fungsi yang strategis untuk menunjang misi dari lembaga induknya membutuhkan suatu wadah semacam gedung. Gedung yang dibutuhkan tidak hanya memenuhi kekuatan bangunan, standar kebutuhan dalam pelayanan yang disediakan dan dikembangkan, akan tetapi juga hendaknya memiliki nilai-nilai seni yang tinggi.

Peran kajian filosofi yang akan dikupas melalui tulisan ini diharapkan dapat menambahkan dasar pemikiran para penggiat kepustakaan lebih mendasar dan kreatif. Pengkajian ini tentunya memiliki keterbatasan penulis, oleh karenanya tujuan penulisan ini sebagai sumbangsih penulisan untuk memperkaya khazanah keilmuan perpustakaan.

\section{B. HASIL DAN PEMBAHASAN}

\section{Arsitektur Posmodern}

Cikal bakal munculnya arsitektur Posmodern dengan adanya pergerakan-pergerakan atau perkembangan-perkembangan di dunia arsitektur. Pada abad ke sembilan belas yaitu tahun 1890, dimulainya babak pergerakan pemikiran di bidang arsitektur. Hingga abad ke dua puluh yaitu tahun 1930 setidakya terjadi pergerakan-pergerakan seperti Art Noveau, Art and Craft, Bauhaus, Ekspresionisme, Rotterdam School, Amsterdam School, dll. Selanjutnya berkembanglah arsitektur modern.

Pada abad ke dua puluh, terdapat dua kelompok yang saling berlawanan, yaitu pihak yang cenderung kepada teknologi dan industrialisasi. Hal ini terjadi pada tahun 1950 dan sebagai puncak kemajuan arsitektur modern. Pihak yang kedua cenderung memuja artistic dan estetik, justru akan 
memandang bahwa pada tahun ini sebagai titik kemerosotan arsitektur modern.

Perkembangan pertentangan sudut pandang tersebut dipercepat melalui media massa sehingga akhirnya muncul faham posmodernisme. Hal ini terjadi pada tahun 1960an.

Perbedaan karakter modernisme dan Posmodernisme ; modernisme : singular, seragam, tunggal, sedangkan posmodernisme : plural, beraneka ragam, bhinneka.

Di dalam tulisan Iwan F. Setiawan dalam judul Arsitektur Modern, Pengertian Postmodern dan Arsitektur Postmodern ${ }^{1}$, mengupas banyak hal tentang arsitektur modern dan posmodern.

\section{Sebuah Gambaran tentang Posmodern}

Makna postmodern dapat diartikan sebagai usainya masa modern, atau dengan istilah lain setelah modern, kelanjutan modern, atau yang semacamnya. Namun pada dasarnya postmodern merupakan cara pikir, cara pandang, bentuk filsafat, sebuah ide, sebuah gagasan baru, bahkan muncul sebuah konsep atau teori baru mengenai arsitektur. Sebagian pula menyatakan bahwa modern terus berlangsung hanya saja ada pembaharuan atau proses adaptasi terhadap perkembangan pada masa selanjutnya.

Perkembangan arsitektur yang memiliki dinamika yang cukup beragam menjadikan banyak priode-priode dengan namanya yang merupakan versi atau tahapan para pelaku arsitektur dan ahli konsep arsitektur. Pada kenyataannya dari hasil karya arsitektur masa itu, versi ini menjadi tiga yaitu purna modern, neo modern dan dekonstruksi. Masing-masing pengikut versi tersebut menamakan kelompoknya dengan istilah-istilah tersebut.

Versi Purna Modern berkarakteristik antara lain: Purna modern adalah bentuk indonesianya dari posmodern model Charles Jencks, pengertian versi Jencks sebetulnya berbeda dengan pengertian postmodern secara umum; versi ini ditandai munculnya berbagai dekorasi, ornamen, dan unsur-unsur kuno bersumber dari pra modern, selanjutnya dengan melakukan transformasi terhadap unsur-unsur kuno tersebut; menggunakan unsur warna dan tekstur sebagai elemen arsitektur penting dan ikut dimodifikasi dengan ruang dan bentuk; Tokohnya yang lain : Michael Graves, Terry Farrell, dan

1 Iwan F. Setiawan, Arsitektur Modern, Pengertian Postmodern dan Arsitektur Postmodern, Lihat http://iwan-arsitekkidal.blogspot.com/2011/07/arsitekturmodern 8359.html, diakses tanggal 7 Desember 2018 
Robert Venturi; diantara aliran arsitektur posmodern yaitu arsitektur purna modern. Dalam perkembangan arsitektur purna modern, terdapat satu masa yang dinamakan modern klassicism, berkisar pada tahun 1950an, membekunya modernisme menjadikan hal-hal bersifat reduktif dalam estetika, terpecah belah, dan terlalu sederhana dalam pedekatan desain. Karena kurangnya kontradiksi internalnya sendiri, modernisme mendekati kehancuran, namun modernisme tersebut dapat pula dikatakan sukses di beberapa hal, dalam prosesnya modernisme ini menghasilkan banyak bangunan yang indah. Berdasarkan fenomena ini, bahkan yang harus dipertanyakan pada modernisme adalah konsepnya; Aliran Renaissance memiliki pengaruh kuat di dalam aliran modern klassicism ini, aliran modern klassicism merupakan aliran yang memadukan ciri utama arsitektur modern dengan arsitektur klasik dalam industrialisasinya, struktur bangunan paling ditonjolkan adalah penggunaan inovasi teknologinya; Dengan gagasan modern classicism ini, arsitektur mendapatkan kembali perannya yang selalu berkembang.

Ada lima pendekatan mengenai classicism yaitu Ironic Classicism, Latent Classicism, Fundamentalist Classicism, Canonic Classicism, dan Modern Tradisionalism. Ciri dari aliran Ironic Classicism adalah sebagai pengganti determinisme dari modernisme yang teknologis dan fungsionalis dengan tanpa mengandung arti, unsur-unsur klasik bisa diikutkan ke dalam arsitektur ini akan tetapi akan selalu dengan tanda-tanya, unsur-unsur berdasarkan atas sejarah berfungsi kepura-puraan walaupun bermanfaat guna, adapun usahanya untuk tujuan menghibur dapat mengakibatkan eksegerasi dan akhirnya menghasilkan bentuk yang aneh bahkan terkesan buruk. Adapun ciri dari latent classicism adalah menggabungkan estetika hasil dari teknologi modernisme dengan prinsip komposisi dari classicism, walupun menggunakan hirarki komposisi di dalam classicism, namun latenta classicism tidak menggunakan kata formal bermuatan simbolis yang ada pada classicism. Adapun ciri fundamentalist Classicism adalah berusaha mengurangi bangunan hingga ke bentuk geometris yang paling murni, pada usahanya dalam mendapatkan kebenaran pokok yang alami, menolak pemakaian bahasa yang sulit dari high classicism, fundamentalist classicism ini menolak secara total modernisme. Adapun ciri dari canonic classicism adalah menolak juga gerakan modernisme secara tegas, tetapi canonic suka akan bahasa tinggi classicism dan otoritas pada masa lampau, bagi kaum canonic classist, seni arsitektur meskipun ia terikat pada evolusi budaya, akan tetapi tidak mempunyai kewajiban khusus untuk berkembang dalam hubungan yang langsung dengan perubahan social. Modern tradisionalism adalah sebuah aliran yangmana bangunan tradisional bisa dilihat layaknya 
bangunan tradisional, padahal sesungguhnya bangunan tersebut adalah bagian dari suatu teknologi, desain, dan memiliki identitas estetik dan momen sejarah.

Adapun karakteristik Neo Modern adalah memiliki gaya arsitektur yang merupakan salah satu aliran arsitektur berkembang di masa posmodern, Charles Jenks menyebutkan bahwa neo modern dimasukkan ke dalam late modern. Neo modern adalah kelanjutan dari arsitektur modern, namun karyakarya arsitek neo modern cenderung bersifat estetis, dan cenderung berkembang pada penggunaan teknologi dan bentuknya secara morfologi seandainya dibandingkan dengan arsitektur modern, yangmana bangunan arsitektur modern masih terlihat polos dan sedikit ornamen, sementara masa neo modern ini mulailah ditambah, dengan beberapa pertimbangan khusus, kemudian diolah sedemikian rupa; teknologi sangat dipentingkan disini, konsep-konsep modern mulai ditampakkan, tetapi masih perlu lebih diolah lagi. Bangunan neo modern merupakan bangunan menggunakan teknologi tinggi, akan tetapi masih masuk akal, dan fungsional; tidak menampilkan dekorasi dan ornamen yang lama namun menonjolkan tektonika atau the art of construction. Arsitekturnya muncul dengan memamerkan kecanggihan teknologi dan kemutakhiran teknologi; tidak terlihat jauh berbeda dengan arsitektur modern yaitu menunjukkan penampilan geometri; menunjukkan bentuk tri-matra hasil dari teknik proyeksi dwi-matra, misalnya tampak sebagai proyeksi denah. Tetapi, juga menghadirkan bentukan tri-matra murni, bukan proyeksi dari bentuk dwi-matra; tokohnya antara lain: Renzo Piano, Richard Meier, Richard Rogers, Norman Foster; penampilan utamanya bentuk geometri; tidak mengutamakan warna dan tekstur, akan tetapi hanya ditampilkan sebagai aksen. Walaupun demikian, warna favoritnya yaitu warna perak.

Arsitektur dekonstruksi adalah pengembangan dari arsitektur modern. Arsitektur dekonstruksi muncul diperkirakan pada tahun 1988 pada diskusi berjudul "Academy Forum" di Tate Gallery, London. Lalu muncul pameran di "Museum of Art", New York dengan judul "Deconstructivist Archiecture" yang diatur dan manajemeni oleh Philip Johnson, terdapat 7 arsitek dan menunjukkan karyanya, yaitu; Bernard Tschumi, Peter Esienman, Daneil Libeskind, Zaha Hadid, Frank Gerhy, Rem Koolhaas, dan Coop Himmelblau. Tema "Dekon" dalam arsitektur kala itu telah menjadi suatu perdebatan hangat dengan karyanya dan mendobrak syarat-syarat yang diberlakukan; Pada tanggal 8 April 1988 diselenggarakan "International Symposium on Deconstruction" oleh Academy Group di Tate Gallery, ditetapkan bahwa dekonstruksi tidaklah gerakan yang satu-satunya atau koheren, meskipun 
diwarnai banyak kemiripan formal diantara karya-karya arsitek satu sama lain. Dekonstruksi tidak mempunya ideologi atau tujuan formal, melainkan semangat mengembangkan kebakuan dan kemapaman. Aliran dekonstruksi awalnya tumbuh dan berkembang di lingkungan arsitek Inggris dan Perancis, kemudian oleh Mark Wigley dan Philip Johnson dengan menyelenggarakan pameran di Museum of Art, New York, tanggal 23 Juni - 30 Agustus 1988 berjudul "Deconstructivist Architecture". Pada pameran tersebut mencetuskan dekonstruktivisme yang berkonotasi lebih pada pragmatis dan formal kemudian berkembang di Amerika. Penelaah dan pengenalan makna dekonstruksi membutuhkan suatu persiapan untuk menerima sejumlah kemungkinan dalam phenomena yang ada. Syarat-syarat ini berlandaskan keterbukaan dan kesabaran. Keterbukaan memberikan kesempatan phenomena untuk berbicara langsung. Kesabaran memberikan kesempatan orang agar mendengarkan lebih cermat dan lebih seksama. Konsep dekonstrusi Perancis diperkenalkan oleh Jacques Derrida, lahir pada tahun 1921, sulit untuk disampaikan seperti pemahaman dan pengertian orang mngenai konstruksi, rekonstruksi, dan destruksi. Derrida membuat para arsitek dan semua orang agar kembali merenungkan hakekat sebuah karya agar berbicara dan menunjukkan menurut pesona dan kapasitasnya. Keseluruhan ini bermula dari metoda komposisi. Derrida memberikan gambaran dengan menyebutkan dan merajut serangkaian hubunganhubungan dan terdapat sejumlah teknik dan terminologi untuk diklarifikasikan. Usaha demikian diharapkan bisa memperjelas hubungan dekonstruksi dan rancang bangunan. Konsep utamanya mengadakan karya bertolak dari konsep yang disebut differance oleh Derrida.

Daya tarik deconstruction pada dunia rancang bangun terdapat pada bagaimana memandangnya bahwa sahnya bentuk dan ruang merupakan tempat terjadinya dan layak terbuka bagi yang mungkin dan yang tidak mungkin. Derrida dengan jelas menolak pendapat bahwa dekonstruksi adalah sebuah aliran atau versi baru pada seni bangunan. Akan tetapi kenyataannya bahwa tidak dapat dipungkiri bahwa apa pun yang dinamakan arsitektur dekonstruksi bisa memberikan dan membuat arsitek kepada arah dan gerakan baru.

Konsep lainnya adalah geometri yang juga secara dominan dalam penampilannya dengan menggunakan geometri 3 dimensi yang bukan dari hasil proyeksi 2 dimensi akhirnya timbul kesan semrawut dan miring. Konsep ini lebih menggunakan warna sebagai rancangannya dalam komposisi sedangkan tekstur dan bentuk kurang banyak berperan. Tokoh 
konsep ini diantaranya ialah Bernard Tschumi, Peter Eisenman, Frank O'Gehry, dan Zaha Hadid.

Perbedaan pokok pikiran arsitek posmodern seperti yang dipaparkan di atas akan berbeda dengan pokok pikiran arsitek modern. Setidaknya ada tiga perbedaan penting yaitu bentuk, ruang dan fungsi. Adapun fungsinya tidak memakai semboyan Form Follows Function, fungsinya bukan pada apa yang dikerjakan manusia mengenai arsitektur dan bukan pula sebagai aktivitas saja.

Arsitektur posmodern tidak mewadahi atau membentuk arsitektur akan tetapi arsitektur postmodern mengkomunikasikan arsitektur yang artinya bahwa arsitektur didefinisikan sebagai sebuah bahasa. Apa sesungguhnya yang dikomunikasikan oleh arsitektur postmodern. Tiga periode yang berbeda-beda, yaitu Purna Modern yang mengkomunikasikan identitas regional, identitas historikal atau identitas kultural. Pada periode ini mengkomunikasikan hal-hal di masa silam, agar orang masa setelahnya mengetahui bahwa arsitektur sebagai bagian dari perjalanan sejarah manusia. Priode Neo Modern berusaha mengkomunikasikan keterlibatan teknologi dan bahan lainnya agar berperan sebagai unsur artistik (seni) dan estetik (keindahan), hal ini yang paling dominan. Sementara Dekonstruksi mengkomunikasikan unsur apa yang paling mendasar, essensial, substansial pada arsitektur dan kemampuan maksimal dari unsur-unsur tersebut di atas.

Melihat kepada prinsip-prinsip dan nilai tersebut, maka dapat pula disimpulkan bahwa Arsitektur Purna Modern memiliki kepedulian terhadap masa silam, Arsitektur Neo Modern memiliki kepedulian terhadap masa ini, sedangkan Arsitektur Dekonstruksi tidak mengikatkan dirinya pada dimensi waktu, sehingga para pemikir arsitektur memandang bahwa hal ini merupakan sikap dan cara pandang yang bersifat atau bernilai "kesombongan" dari arsitek Dekonstruksi.

Membahas masalah "fungsi" dalam arsitektur seperti yang telah disinggung di atas, maka akan dilihat apa makna "fungsi" yang dimaksud. Fungsi yang dimaksudkan di sini adalah peran bukan "aktivitas", bukan pula apa yang manusia lakukan terhadap arsitektur. Dengan demikian dalam arsitektur posmodern fungsi dimaksudkan peran dan daya guna arsitektur untuk melayani manusia dan bahkan mempengaruhinya. Pengaruh yang diciptakannya karena konsep manusia yang dimaksudkan yaitu manusia sebagai makhluk memiliki daya pikir, melakukan aktivitas, memiliki perasaan, memiliki nostalgia, memiliki memori, serta makhluk yang mempunyai mimpi dan ambisi. 
Arsitektur Posmodern merancang fungsi arsitektur sebagai berikut: 1). memberikan perlindungan kepada manusia dari ancaman fisik; 2). arsitektur memberikan perlindungan kepada manusia dari ancaman psikis, memerikan perasaan aman dan nyaman; 3). arsitektur menyediakan dirinya bagi manusia untuk berbagai tujuan; 4). menyadarkan manusia terhadap budaya dan peradaban masa silam; 5). memberi kesempatan pada manusia untuk menggapai impian dan khayalan; 6). memberi gambaran terhadap fenomena dan kenyataan yang ada.

\section{Bentuk dan Ruang}

Didalam arsitektur posmodern, dua komponen bentuk dan ruang memiliki kemandirian dalam mempengaruhi arsitektur, mereka tidak harus memiliki hubungan sebab akibat. Keduanya mandiri sehingga dapat saja dihubungkan atau pun tidak.

Keberadaan arsitektur Posmodern di Indonesia sudah ada sejak tahun 1970an. Adapun karya pada saat itu adalah dari Y.B Mangunwijaya. Akan tetapi bila diobservasi dan dikaji secara visual, maka versi posmodern masih belum populer di Indonesia. Tokoh-tokoh Indonesia yang berusaha menghadirkan versi Posmodern ini adalah antara lain: Yori Antar, Sonny Sutanto, Sardjono Sani, dan lain-lain.

\section{Arsitektur Posmodern Sebagai Koreksi Arsitektur Modern}

Perkembangan arsitektur sebagai karya seni seiring dengan perkembangan manusia yang membutuhkan konsep arsitektur. Sejak zaman Yunani dan Romawi misalnya hingga sekarang ini, bisa dilihat perkembangannya. Sebagai akibat kebutuhan dan daya piker manusia maka muncullah perkembangan arsitektur hingga arsitektur modern. Kebutuhan manusia akan kehadiran arsitektur modern pada saat itu dipengaruhi banyak factor antara lain; adanya kehancuran bangunan-bangunan setelah perang dunia kedua dan membutuhkan pembangunan kembali secara singkat dan efektif; selain itu dengan berkembangnya industri-industri yang menyediakan kebutuhan bahan untuk pembangunan serta didukung juga dengan penemuanpenemuan material bangunan seperti bahan beton, baja, kaca dan lain-lain.

Setelah perang dunia kedua, bangunan yang dibuat lebih kepada fungsinya pada saat itu dan pembangunan di mana-mana terjadi. Seni atau ornament bangunan arsitektur klasik tidak terpakai lagi. Pada saat itu orang mengganggap bahwa arsitektur modern tidak akan bertahan untuk jangka waktu lama karena dijumpai kelemahan pada arsitektur modern, misalnya hilangnya desain atau bentuk seni, hal ini dikarenakan tuntutan produksi; 
tidak lagi memiliki nilai peradaban budaya kedaerahan dan dianggap bersifat kapitalisme.

Bahwa pembagian arsitektur modern adalah ke dalam 3 waktu yakni modern awal tahun 1890 hingga 1910, modern puncak tahun 1920 hingga tahun 1950, dan modern akhir dari tahun 1950 hingga tahun 1960.

Pada masa pertengahan tahun 1960, konsep baru mengenai arsitektur sudah muncul yang nantinya akan menggantikan konsep arsitektur modern. Konsep tersebut muncul dalam buku "Complexcity and Contradiction in Architecture" oleh Robert Venturi dan buku " the Architecture of the City" oleh Aldo Rossi. Dengan demikian, mulai berakhirnya arsitektur modern. Arsitektur baru yang muncul tersebut dinamakan arsitektur posmodern. Harapan munculnya arsitektur posmodern ini agar dapat menjawab permasalahan-permasalahan dan kritikan yang sudah ada pada arsitektur modern. Dalam konsep dan teori arsitektur posmodern, karyanya kembali memadukan seni dan ilmu. Arsitektur posmodern menempatkan proses komunikasi dan bahasa menjadi bermakna dan bisa menyentuh kembali aspek kemanusiaan.

Seorang tokoh arsitek postmodern, Charles A.Jencks, mengungkapkan pendapatnya bahwa konsep arsitektur itu sama dengan konsep bahasa. Sebagaimana bahasa yang terdiri dari kata-kata, begitu juga arsitektur terdiri dari unsur-unsurnya seperti tiang, dinging, atap, dan lainlain. lebih lanjut beliau menyatakan bahwa unsur-unsur komunikasi pada bangunan adalah sintak, sematik, methapor. Sintak dimaksudkan bahwa penyusunan komponen arsitektur akan memiliki makna atau ide tertentu. Semantik dimaksudkannya adalah makna tertentu dari keseluruhan arsitektur yang menjadi ciri khas penggunaannya. Methapor dimaksudkan adalah menunjukkan suatu simbol yang diperoleh dari bentukan alam yang maknanya kiasan. Arsitektur ditempatkan sebagai atau bagaikan sebuah bahasa atau komunikasi bertujuan mengakomodir aspek kemanusiaan. Hadirnya arsitektur posmodern sebagai bentuk kepekaan terhadap apa yang dihadapi oleh manusia.

Pemikiran tentang arsitektur post modern dan aliran post modern atau postmoderisme banyak dikupas di dalam tulisan para ahli arsitektur. Di 
antara tulisan yang ada dalam media online yaitu oleh Kami No Kanshin yang berjudul Arsitektur Post Modern dan Postmoderisme. ${ }^{2}$

\section{Tentang Estetika dalam Arsitektur}

Alasan mengupas mengenai estetika merupakan sebuah pertanyaan. Hal ini dikarenakan bahwa estetika cukup penting agar bangunan lebih mudah dimengerti dengan menggunakan estetika sebagai suatu alat, dan terlebih lagi karena estetika biasanya berbeda untuk setiap orang. Sama halnya arsitektur sebagai bahasa, jika tanpa bahasa, pengetahuan mudah disampaikan. Estetika di dalam konsep arsitektur adalah sebuah bahasa visual, yang tidak sama dengan bahasa yang tidak visual. Estetika dalam arsitektur memiliki banyak kaitannya dengan semua yang bersifat visual seperti volume, permukaan, elemen garis, massa, dan sebagainya, termasuk di dalamnya berbagai order harmoni dalam komposisi.

Estetika meskipun berkaitan dengan 'rasa' saat melihat bangunan juga dapat dibangun melalui aplikasi teori arsitektur. Inilah mengapa estetika patut dibahasakan dan dibahas dalam alat yang bernama komunikasi. Estetika dapat dimengerti dan dikembangkan melalui pemahaman berbagai hal menyangkut teori estetika, menjadi dasar bagi banyak cabang seni. Namun melihat berbagai dimensi yang mempengaruhi bagaimana seorang manusia mengapresiasi keindahan, estetika hanyalah sebuah media untuk mencoba menjelaskan apa yang disebut indah, namun tidak pernah bisa menjelaskan apa yang sebenarnya terjadi dalam benak seseorang berkaitan dengan sensasi keindahan. Dalam teori tentang estetika, dicoba dijelaskan berbagai sisi yang 'tersentuh' oleh keindahan sebuah obyek. Jadi, apa yang indah bagi saya belum tentu indah bagi Anda.

Meskipun estetika erat hubungannya dengan rasa, akan tetapi bangunan dalam konsep arsitektur juga dapat dilaksanakan melalui aplikasi teori-teori arsitektur. Melihat hal ini, maka alasan kemudian estetika layak disepadankan dengan konsep bahasa dan dibahasakan serta dibahas dalam konsep komunikasi. Estetika akan dapat difahami, dimengerti, dilakukan dan dikembangkan melalui pengkajian banyak hal mendasar tentang teori estetika, lalu dasar-dasar tersebut menjadi landasan bagi cabang seni atau estetika. Melihat banyak dimensi dan sudut pandang yang mempengaruhi manusia dalam menilai dan mengapresiasi keindahan, maka estetika hanya sebagai media dalam menjelaskan apa yang disebut dengan keindahan, akan

2 Kami No Kanshin, Arsitektur Post Modern dan Postmoderisme , Lihat http://kaminokanshin.blogspot.com/2014/09/post-modern-arsitektur-dan-pengertian.html, diakses tanggal 12 Desember 2018. 
tetapi tidak mampu menggambarkan apa yang sesungguhnya terjadi dalam fikiran seseorang terkait dengan sensasi keindahan. Teori estetika mencoba menjelaskan bermacam sudut pandang menyentuh keindahan sebuah sebuah obyek. Oleh karena itu, pada akhirnya nilai keindahan sepertinya relatif, namun dengan konsep-konsep yang jelas kita dapat menilai secara obyektif.

\section{Dimana Arsitektur (khas kedaerahan) Indonesia?}

Indonesia dengan segala aktifitasnya, terdiri dari banyak suku dan budaya, memiliki sebuah sistem kehidupan masyarakat yang memperhatikan kebutuhan pokok. Kebutuhan pokok antara lain yaitu tempat dimana masyarakat hidup. Segala sesuatu yang berkaitan dengan arsitektur yang dimiliki orang Indonesia kemudian disebut arsitektur Indonesia. dengan demikian dapat kita perkirakan bahwa arsitektur di Indonesia banyak dan beragam, dari penjuru Sabang hingga Merauke.

Agus Darma dalam tulisannya menyampaikan bahwa: ${ }^{3}$

Seni bangunan sebenarnya adalah suatu bidang kesenian yang amat cocok untuk dapat mempertinggi rasa kebanggaan dan identitas suatu bangsa. Wujudnya sangat fisik dan lokasinya di kota-kota besar yang sering dikunjungi oleh bangsa-bangsa dari seluruh penjuru mata angin, sehingga dapat tampak dari luar. Sifat khasnya bisa mudah ditonjolkan sedangkan mutunya pun mudah dapat diobservasi.

Melihat banyaknya bentuk arsitektur di Indonesia yang dipengaruhi oleh nilai-nilai budaya daerah, sehingga istilah arsitektur Indonesia masih belum tepat. Istilah yang lebih tepat adalah arsitektur kedaerahan di Indonesia. Arsitektur di Indonesia mungkin adalah arsitektur yang sedang tren dan diikuti seperti minimalis atau tidak minimalis, klasik, mediterania, dan lain-lainnya. Kemungkinan model-model kontemporer yang banyak dikembangkan yaitu mensinergikan arsitektur masa sekarang atau modern dengan model tradisional.

Ragam arsitektur yang paling banyak ada di Indonesia sehingga kondisi ini tidak dimiliki oleh negara-negara lain. Inilah yang dikenal arsitektur khas di Indonesia.

\footnotetext{
${ }^{3}$ Agus Dharma, Aplikasi Regionalisme dalam Desain Arsitektur, Lihat (https://www.researchgate.net/profile/Agus_Tohjiwa/publication/267830209_APLIKASI_R EGIONALISME_DALAM_DESAIN_ARSITEKTUR/links/5476a2d20cf245eb43727b8a/A PLIKASI-REGIONALISME-DALAM-DESAIN-ARSITEKTUR.pdf), diakses pada tanggal 11 Desember 2018
} 
Negara yang sedang berkembang biasanya memungkinkan mengakomodir nilai-nilai yang dianggap baik untuk mengembangkan negara termasuk dari sisi arsitektur. Kajian-kajian dari negara-negara maju sangat berpengaruh kepada bidang-bidang kajian penting termasuk arsitektur. Para ahli arsitektur Indonesia pun ketika mengkaji atau menulis tentang arsitektur berkembang di dunia, cenderung tidak melibatkan arsitektur di Indonesia, hal ini dikarenakan literatur atau tulisan konsep-konsep artitektur di Indonesia belum banyak dijumpai. Sehingga arsitektur di Indonesia kalah pamor dibangding dengan konsep arsitektur dunia.

\section{Gaya Arsitektur Modern di Indonesia}

Arsitektur modern tidak berkembang baik di Indonesia, gaya arsitektur ini ada muncul di Indonesia pengaruh dari globalisasi. Arsitektur modern merupakan model gaya internasional yang memang mempunyai kemiripan di semua daerah dan semua negara. Kesamaan gaya modern dan gaya arsitektur Indonesia karena semua mengusung fungsi ruang sebagai titik awal arsitektur.

Gaya hidup masyarakat di Indonesia dalam seni arsitektur, berimbas kepada keinginan membangun bangunan yang sederhana, bersih dan memiliki fungsi-fungsi, hal ini sepertinya merupakan simbol dari semangat modern. Tidak semua masyarakat melakukan gaya ini, gaya semacam ini hanya dilakukan oleh sebagian masyarakat kota besar dimana kehidupan bagi mereka menuntut cara hidup yang lebih fungsional, cepat dan efisien.

Model arsitektur di Indonesia masih mengandung bentuk-bentuk estetika yang bersumber dari model klasik atau ektik, namun memang sebagian lagi sudah menggunakan model-model arsitektur modern. Oleh karenanya muncullah istilah arsitektur modern etnik, arsitektur tradisional modern, arsitektur klasik modern, arsitektur bali modern, dan sebagainya.

Dalam sebuah sumber online dipaparkan bahwa ada lima gaya arsitektur modern di Indonesia dengan karakter sebagai berikut: 1) memiliki perhatian yang besar terhadap fungsi ruang yang didapatkan dari pola aktivitas penghuninya, 2) memiliki perhatian yang besar terhadap material bangunan yang digunakan untuk mendapatkan hasil akhir (estetika) yang diinginkan, 3) memiliki analogi mesin dalam penataan dan pengembangan ruang-ruang, 4) menghindari ornamen (bila murni gaya modern), atau menggunakan ornamen (bila posmodern, atau diberi embel-embel semacam arsitektur modern etnik, arsitektur modern Bali dan sebagainya, 5) 
penyederhanaan bentuk dan ornamentasi dan penghilangan detail yang tidak diperlukan sejauh keinginan desainer atau pemilik bangunan. ${ }^{4}$

Dalam sumber lain dinyatakan bahwa ada 6 ciri khas arsitek modern yaitu 1) Kesederhanaan sampai ke dalam inti desain, 2) Elemen garis yang simetris dan bersih, 3) Prinsip Less is More, 4) Kejujuran dalam penggunaan material, 5) Rancangan yang terbuka dengan banyak elemen kaca, 6) Hubungan dengan lingkungan sekitar. ${ }^{5}$

\section{Filosofis Bangunan Perpustakaan}

Yang dimaksud dengan bangunan perpustakaan disini adalah meliputi gedung dan tata ruang untuk pelayanan perpustakaan. Bentuk gedung biasanya akan mengikuti perkembangan seni bangunan (arsitektur) pada tempat tertentu, di Sumatera misalnya bentuk bangunan yang sudah dicontohkan oleh orang-orang terdahulu akan banyak mempengaruhi bentuk bangunan pada saat sekarang termasuk gedung perpustakaan.

Eka Susanti dan Budiono dalam tulisannya berjudul Desain Interior Perpustakaan sebagai Sarana Edukasi dan Hiburan dengan Konsep Post Modern, ${ }^{6}$ Penelitian yang dilakukan mereka adalah untuk melihat kebutuhan perpustakaan untuk meningkatkan minat baca melalui desain interior perpustakaan. Pengumpulan data penting dilakukan dengan kuistioner, wawancara dan pengamatan. Data pendukung untuk menilai dari aspek arsitektur menggunakan konsep Post Modern. Hasil yang diperoleh dari penelitian ini adalah bahwa konsep keindahan interior dengan bersifat nyaman, hangat dan kekeluargaan akan memecahkan kekakuan. Terlebih paradigma masyarakat bahwa perpustakaan adalah sebuah tempat yang membosankan dan tidak menarik.

Resti Noviani, Agus Rusmana, dan Saleha Rodiah dalam tulisan berjudul Peranan Desain Interior Perpustakaan dalam Menumbuhkan Minat

${ }^{4}$ ArcDesign forum and community, Gaya Arsitektur Modern di Indonesia, Lihat https://netsain.wordpress.com/2009/10/10/gaya-arsitektur-modern-di-indonesia/ diakses tanggal 9 Desember 2018

${ }^{5}$ Kania Dekoruma, 6 Ciri Khas Menarik dari Arsitektur Modern, kamu harus tau, Lihat https://www.dekoruma.com/artikel/63228/ciri-khas-arsitektur-modern

${ }^{6}$ Eka Susanti dan Budiono, Desain Interior Perpustakaan sebagai Sarana Edukasi dan Hiburan dengan Konsep Post Modern, JURNAL SAINS DAN SENI POMITS Vol. 3, No.1, (2014), lihat

https://media.neliti.com/media/publications/15374-ID-desain-interior-perpustakaansebagai-sarana-edukasi-dan-hiburan-dengan-konsep-po.pdf, diakses tanggal 12 Desember 2018 
pada Ruang Perpustakaan, ${ }^{7}$ Penelitian mereka bertujuan untuk mengetahui peran ruang, aksesoris, prabot, pewarnaan, pencahayaan, dan sirkulasi udara dalam menumbuhkan minat pemustka untuk mendatangi perpustakaan. Hasil penelitian menunjukkan bahwa semua obyek yang dijadikan penilaian semua berperan penting dalam meningkatkan minat pemustaka untuk mendatangi perpustakaan.

Dalam posmodern, perancangan dimulai dengan melakukan analisa fungsi arsitektur, yaitu: 1) Arsitektur mempunyai fungsi memberi perlindungan kepada manusia (baik melindungi nyawa maupun harta, mulai nyamuk sampai bom), 2) Arsitektur memberikan perasaan aman, nyaman, nikmat, Arsitektur mempunyai fungsi untuk menyediakan dirinya dipakai manusia untuk berbagai keperluan, 3) Arsitektur berfungsi untuk menyadarkan manusia akan budayanya akan masa silamnya, 4) Arsitektur memberi kesempatan pada manusia untuk bermimpi dan berkhayal, 5) Arsitektur memberi gambaran dan kenyataan yang sejujur-jujurnya. ${ }^{8}$

Melihat prinsip-prinsip di atas maka pembangunan gedung perpustakaan tidak memiliki perbedaan yang mendasar. Bangunan yang dirancang harus memenuhi fungsinya yang pertama yaitu memberikan perlindungan kepada petugas dan masyarakat pemustaka dalam hal ini gedung tersebut harus memberikan rasa aman. Kenyamanan kegiatan pelayanan yang ada di perpustakaan baik bagi petugas dan pustakawan yang akan memberikan pelayanan dan melakukan kreativitas, juga bagi masyarakat pemustaka yang menikmati layanan. Dalam hal ini, gedung perpustakaan dibangun dengan menggunakan konsep kenyamanan. Pada keadaan tertentu yang dipengaruhi lingkungan, manusia akan merasa nyaman sehingga pada masyarakat mepustaka tertentu memiliki rasa nyaman yang berbeda pula. Fungsi lain gedung perpustakaan yaitu untuk menyadarkan manusia akan budaya silam. Berkaitan dengan prinsip yang ini, nampaknya perpustakaan adalah tempat yang tepat untuk mewujudkannya. Tidak hanya sebagai penyimpan khasanah budaya, akan tetapi gedung perpustakaan secara langsung didesain menggambarkan khasanah budaya bagi masyarakat pemustakanya. Dengan prinsip gedung dapat memberikan kesempatan pada manusia untuk bermimpi dan berkhayal, memungkinkan perencanaan gedung perpustakaan memerlukan ahli-ahli desain unggul untuk menampakan apa

7 Resti Noviani, Agus Rusmana, dan Saleha Rodiah, Peranan Desain Interior Perpustakaan dalam Menumbuhkan Minat pada Ruang Perpustakaan, JURNAL KAJIAN INFORMASI \& PERPUSTAKAAN, Vol.2/No.1, Juni 2014, hlm.37-46

${ }^{8}$ Wahana Arsitektur Indonesia, Arsitektur Post Modern, lihat http://wahana-arsitekturindonesia.blogspot.com/2011/12/arsitektur-post-modern.html 
yang menjadi dambaan bagi masyarakat pemustaka terhadap kehidupan. Hal ini dapat berupa bentuk tata ruang pelayanan yang menggambarkan keromantisan, keakraban, jauh dari ketidakmenentuan, ketertiban, dan lainlain. Pada prinsip fungsi terakhir yaitu gedung perpustakaan mampu memberikan gambaran dan kenyataan yang sejujur-jujurnya. Maksud prinsip ini adalah memungkinkan gedung perpustakaan didesain untuk menunjukkan kepada masyarakat pemustaka bahwa kita manusia sangat tergantung dengan alam. Manusia yang mampu mempertahankan kelangsungan keharmonisan hubungan antara manusia dengan makhluk-makhluk yang lain.

Untuk mewujudkan prinsip-prinsip paradigma pembangunan gedung di atas ada dua hal pokok yang nampaknya harus dimiliki, yaitu kemampuan ahli-ahli desain gedung yang mumpuni dengan rancangan yang matang berdasarkan paradigma yang sama, dan tersedianya kemampuan secara finansial untuk mewujudkan rancangan yang sudah dibuat.

Yusri Fahmi dalam tulisannya Desain Gedung Perpustakaan Perguruan Tinggi (Antara Fungsi dan Estetika), menuliskan nilai-nilai yang menjadi pertimbangan para desainer gedung perpustakaan sehingga manfaat gedung dapat berfungsi menunjang fungsi-fungsi perpustakaan itu sendiri. Beberapa hal yang yang menjadi penyebab terjadinya ketidaksesuaian gedung dengan fungsinya antara lain karena tiga hal: pertama, karena tidak ada komunikasi antara pimpinan dan pustakawan dalam merancang gedung perpustakaan, kedua, tidak ada komunikasi antara para arsitek dengan pustakawan, dan ketiga, para pustakawan sendiri yang tidak mengetahui konsep arsitektur bangunan perpustakaan. ${ }^{9}$

\section{Bagaimana Filosofis Bangunan Perpustakaan Indonesia?}

Pada dekade tahun 70an - 80an, bentuk bangunan di Indonesia masih merujuk pada bentuk kedaerahan, hal ini masih banyak dipengaruhi oleh para perancang bangunan dan tenaga-tenaga kasarnya masih sangat mahir dengan apa yang sudah diturunkan nenek moyang terlebih lagi kentalnya budaya kedaerahan yang ditanamkan masyarakat pada saat itu. Peran teknologi telekomunikasi dan informasi belum banyak berperan sehingga tenaga-tenaga ahli daerah masih sulit memahami dan menguasai bentukan-bentukan lain dari bangunan kedaerahan.

${ }^{9}$ Yusri Fahmi, Desain Gedung Perpustakaan Perguruan Tinggi (Antara Fungsi dan Estetika), Khizanah al-Hikmah, Vol.1 No.2 Juli-Desember 2013, lihat http://journal.uinalauddin.ac.id/index.php/khizanah-al-hikmah/article/view/31/12, diakses tanggal 12 Desember 2018. 
Sebenarnya seni bangunan posmodern telah ada di Indonesia pada tahun 70an, akan tetapi masih berada pada daerah-daerah perkotaan yang sudah memiliki infrastuktur teknologi telekomunikasi dan informasi.

Pada dekade 80an ke atas setelah media teknologi telekomunikasi dan informasi mulai masuk di daerah. Banyak hal-hal baru yang cukup dirasakan menjadi sebuah tren bangunan-bangunan penduduk daerah. Khususnya dimulai dari kalangan-kalangan yang telah merambah daerah lain yang lebih maju, dan mereka menjadi contoh bahwa kemajuan dalam bidang seni bangunan sudah mencapai tingkat kemajuan pada pandangan (paradigma) baru dalam memandang bentukan-bentukan sebuah bangunan.

Berkembangnya bentuk bangunan yang terbuat dari bahan baku kedua atau ketiga karena berkurang bahan-bahan utama seperti kayu, rotan dan batu mendukung perubahan-perubahan baru bentukan bangunan di daerah, dan hal ini menjadikan seni bangunan di Indonesia bergerak pada penerimaan pandangan baru.

Budaya bangsa yang terlihat dari bentukan bangunan akan menjadi kenangan lama yang bernilai tinggi dengan prinsip-prinsip bangunan yang pada dasarnya tidak jauh berbeda dengan bentukan di era globalisasi.

Bangunan perpustakaan agak berbeda dengan gedung perumahan, hal ini disebabkan fungsinya yang juga berbeda dengan gedung yang lain. Gedung perpustakaan harus memenuhi kebutuhan lembaga perpustakaan dalam menjalankan fungsinya sebagai penyedia, pengorganisasi, penyimpan, dan pelayanan bahan pustaka. Karena kebutuhan fungsi tersebut gedung perpustakaan cenderung sederhana dengan menggunakan prinsip efisien tempat.

Seperti dipaparkan di atas bahwa paradigma arsitektur posmodern disandarkan pada polo berfikir bahwa arsitektur dianggap sebagai sebuah bahasa yang dapat mengkomunikasikan konsep arsitekur terhadap sifat budaya tertentu, hal ini menunjukkan bahwa fungsi arsitektur berperan untuk mempengaruhi dan melayani manusia sebagai makhluk komunikastif yang berpikir, bekerja, memiliki perasaan dan emosi, makhluk yang punya mimpi dan ambisi, memiliki nostalgia dan memori, serta bentuk dan ruang.

Dalam arsitektur posmodern, perancangan dimulai dengan melakukan analisa terhadap fungsi arsitektur, yaitu : arsitektur mempunyai fungsi memberi perlindungan kepada manusia, arsitektur memberikan perasaan aman, nyaman, nikmat, arsitektur mempunyai fungsi untuk menyediakan dirinya dipakai manusia untuk berbagai keperluan, arsitektur 
berfungsi untuk menyadarkan manusia akan budayanya akan masa silamnya, arsitektur memberi kesempatan pada manusia untuk bermimpi dan berkhayal, arsitektur memberi gambaran dan kenyataan yang sejujur-jujurnya.

Fungsi rekreasi pada lembaga perpustakaan membuka lebar pandangan para pekerja-pekerja sumber daya informasi dan pengetahuan terhadap bentukan bangunan yang menjadikan perpustakaan tempat yang selalu dirindukan oleh para pemustaka. Pada perpustakaan-perpustakaan perguruan tinggi yang sudah maju seperti perpustakaan-perpustakaan perguruan tinggi di Jakarta katakanlah perpustakaan di Universitas Pelita Harapan, bentukan ruang atau interiornya sangat menarik dan terkesan sangat nyaman. Hal ini baru terjadi pada seni interior tidak pada bentuk bangunannya. Meskipun gedung-gedung perpustakaan di Indonesia masih tergolong kaku yaitu cenderung berbentuk persegi empat.

Di Indonesia prinsip-prinsip itu tidak seluruhnya teradaptasi, tetapi muncul secara terpotong-potong kadang-kadang dalam bentuk yang lebih ekstrem. Akibatnya, tak ada kesinambungan perkembangan seni modern (sebagai paradigma pembaharu) dengan paradigma seni yang menjadi cikal bakal seni Indonesia. Paradigma tersebut seolah menjadi satu dogma seni modern Indonesia yang perlu dipertanyakan.

Kegagapan yang terjadi sebenarnya merupakan bagian dari wacana tekstual yang muncul ke permukaan yang ternyata tidak pernah mampu menjawab wacana seni dalam konteksnya sebagai ketahanan budaya Indonesia yang plural itu (multiculture). Ketahanan budaya yang telah kokoh terbangun sejak kebudayaan Hindu-Budha dan kemudian diteruskan oleh gagasan para wali di zaman Islam klasik Demak sampai Mataram. Seni sebagai satu ajaran (dakwah) dan pewujudan estetik atau sering disebut merupakan tuntunan dan tontonan (hiburan). Fungsi seni tersebut kokoh di tengah masyarakatnya saat itu dalam satu bentuk perwujudan yang integral, - seni integral dengan masyarakatnya. Sampai munculnya seni modern lewat kaum akademik sebagai budaya tandingan, akibatnya masyarakat dihadapkan oleh kebudayaan dua muka yang masing menggelitik dan menjadi wacana pembahasan yang tak pernah habis.

Melihat prinsip-prinsip di atas maka pembangunan gedung perpustakaan tidak memiliki perbedaan yang mendasar. Bangunan yang dirancang harus memenuhi fungsinya yang pertama yaitu memberikan perlindungan kepada petugas dan masyarakat pemustaka dalam hal ini gedung tersebut harus memberikan rasa aman. Kenyamanan kegiatan pelayanan yang ada di perpustakaan baik bagi petugas dan pustakawan yang 
186 |Rahmat Iswanto dan Hasni Hartati: Nilai Filosofis ...

akan memberikan pelayanan dan melakukan kreativitas, juga bagi masyarakat pemustaka yang menikmati layanan. Dalam hal ini, gedung perpustakaan dibangun dengan menggunakan konsep kenyamanan. Pada keadaan tertentu yang dipengaruhi lingkungan, manusia akan merasa nyaman sehingga pada masyarakat mepustaka tertentu memiliki rasa nyaman yang berbeda pula. Fungsi lain gedung perpustakaan yaitu untuk menyadarkan manusia akan budaya silam. Berkaitan dengan prinsip yang ini, nampaknya perpustakaan adalah tempat yang tepat untuk mewujudkannya. Tidak hanya sebagai penyimpan khasanah budaya, akan tetapi gedung perpustakaan secara langsung didesain menggambarkan khasanah budaya bagi masyarakat pemustakanya. Dengan prinsip gedung dapat memberikan kesempatan pada manusia untuk bermimpi dan berkhayal, memungkinkan perencanaan gedung perpustakaan memerlukan ahli-ahli desain unggul untuk menampakan apa yang menjadi dambaan bagi masyarakat pemustaka terhadap kehidupan. Hal ini dapat berupa bentuk tata ruang pelayanan yang menggambarkan keromantisan, keakraban, jauh dari ketidakmenentuan, ketertiban, dan lainlain. Pada prinsip fungsi terakhir yaitu gedung perpustakaan mampu memberikan gambaran dan kenyataan yang sejujur-jujurnya. Maksud prinsip ini adalah memungkinkan gedung perpustakaan didesain untuk menunjukkan kepada masyarakat pemustaka bahwa kita manusia sangat tergantung dengan alam. Manusia yang mampu mempertahankan kelangsungan keharmonisan hubungan antara manusia dengan makhluk-makhluk yang lain.

Untuk mewujudkan prinsip-prinsip paradigma pembangunan gedung di atas ada dua hal pokok yang nampaknya harus dimiliki, yaitu kemampuan ahli-ahli desain gedung yang mumpuni dengan rancangan yang matang berdasarkan paradigma yang sama, dan tersedianya kemampuan secara finansial untuk mewujudkan rancangan yang sudah dibuat.

Penggunaan nilai-nilai filosofi arsitektur posmodern terhadap gedung perpustakaan dapat kita buat analisa sebagai berikut:

\begin{tabular}{|c|c|c|}
\hline No. & Nilai Filosofi & Penerapan \\
\hline 1 & $\begin{array}{l}\text { Fungsi memberi perlindungan } \\
\text { kepada manusia }\end{array}$ & $\begin{array}{l}\text { Gedung perpustakaan seharusnya } \\
\text { menjamin terlaksananya kegiatan } \\
\text { pokok dan tambahan perpustakaan } \\
\text { tanpa ada kendala fisik. Misalnya } \\
\text { untuk menyimpan koleksi, harus } \\
\text { bebas dari gangguan kerusakan } \\
\text { dan kehilangan, untuk pelayanan } \\
\text { sirkulasi harus representatif } \\
\text { terhadap fasilitas yang }\end{array}$ \\
\hline
\end{tabular}




\begin{tabular}{|c|c|c|}
\hline & & 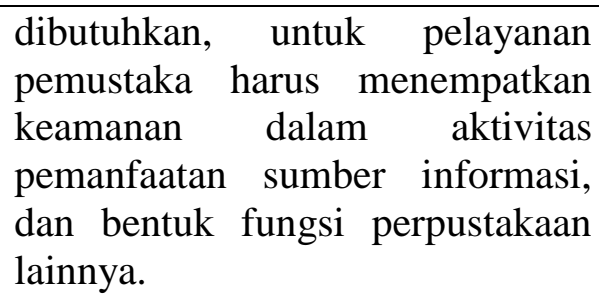 \\
\hline 2 & $\begin{array}{l}\text { Memberikan perasaan nyaman } \\
\text { dan nikmat }\end{array}$ & \begin{tabular}{lr} 
Gedung & \multicolumn{2}{c}{ perpustakaan } \\
memberikan suasana yang \\
nyaman dan mengasikkan \\
sehingga pemustaka akan tertarik \\
untuk terus kembali berkunjung \\
ke perpustakaan.
\end{tabular} \\
\hline 3 & $\begin{array}{l}\text { Berfungsi untuk menyadarkan } \\
\text { manusia akan budayanya akan } \\
\text { masa silamnya }\end{array}$ & 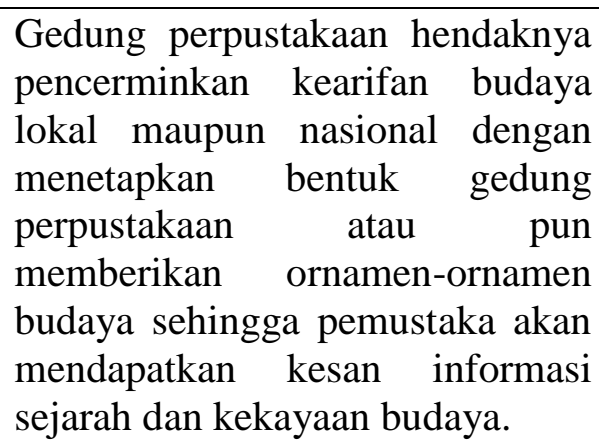 \\
\hline 4 & $\begin{array}{l}\text { Memberi kesempatan pada } \\
\text { manusia untuk bermimpi dan } \\
\text { berkhayal }\end{array}$ & $\begin{array}{l}\text { Gedung perpustakaan } \\
\text { memberikan nuansa metafor yang } \\
\text { menarik dan mendalam. } \\
\text { Pemustaka akan merasa tergugah } \\
\text { untuk mengembangkan dan } \\
\text { memimpikan hal-hal yang terkait } \\
\text { dengan kajian keilmuan mereka. } \\
\text { Hal ini dapat dilakukan dengan } \\
\text { menyediakan sarana berfikir, } \\
\text { ornamen-ornamen keilmuan, } \\
\text { poster menarik, dan lainnya yang } \\
\text { terkait dengan daya imajinasi } \\
\text { terhadap kebutuhan masyarakat } \\
\text { pemustaka. }\end{array}$ \\
\hline 5 & $\begin{array}{l}\text { Memberi gambaran dan } \\
\text { kenyataan yang sejujur-jujurnya }\end{array}$ & \begin{tabular}{lrr} 
Gedung & \multicolumn{2}{r}{ perpustakaan } \\
memberikan informasi & yang \\
sesuai dengan & keadaan & terkini.
\end{tabular} \\
\hline
\end{tabular}


188 Rahmat Iswanto dan Hasni Hartati: Nilai Filosofis ...

\begin{tabular}{|l|l|}
\hline $\mid \begin{array}{l}\text { Hal ini dapat dituangkan dengan } \\
\text { informasi data dengan ruang } \\
\text { lingkup yang beragam seperti data } \\
\text { secara lokal, regional, nasional, } \\
\text { dan internasional. }\end{array}$ \\
\hline
\end{tabular}

\section{KESIMPULAN}

Paradigma posmodern terhadap seni arsitektur di Indonesia telah dapat diterima dan untuk dapat mengembangkan paradigma ini masih perlu kemampuan-kemampuan, ini merupakan gerakan yang berlanjut.

Bentukan-bentukan bangunan pada saat sekarang sangat bebas dan lebih mudah untuk menghitung daya tahan dan fungsi bangunan dengan bantuan penghitungan akurasi menggunakan komputer. Bukan tidak mungkin bangunan-bangunan gedung perpustakaan akan merefleksikan dirinya secara bebas dilihat dari segi estetika gedung dan mampu mengadopsi nilai-nilai filosofi posmodern dengan baik.

Tulisan tentang nilai filosofis bangunan perpustakaan ditinjau dari pemikiran arsitektur posmodern ini banyak memiliki kelemahan dalam menghadirkan sumber rujukan dan kutipan yang terbarukan, oleh karena itu bagi peneliti selanjutnya diharapkan dapat memperkaya dan menempatkan penjelasan yang lebih baik dan aplikatif.

\section{DAFTAR RUJUKAN}

ArcDesign forum and community, Gaya Arsitektur Modern di Indonesia, Lihat https://netsain.wordpress.com/2009/10/10/gaya-arsitekturmodern-di-indonesia/ diakses tanggal 9 Desember 2018

Dekoruma, Kania, 6 Ciri Khas Menarik dari Arsitektur Modern, kamu harus tau, Lihat https://www.dekoruma.com/artikel/63228/ciri-khasarsitektur-modern

Dharma, Agus, Aplikasi Regionalisme dalam Desain Arsitektur, Lihat (https://www.researchgate.net/profile/Agus_Tohjiwa/publication/2678 30209_APLIKASI_REGIONALISME_DALAM_DESAIN_ARSITE KTUR/links/5476a2d20cf245eb43727b8a/APLIKASIREGIONALISME-DALAM-DESAIN-ARSITEKTUR.pdf), diakses pada tanggal 11 Desember 2018

Fahmi, Yusri, Desain Gedung Perpustakaan Perguruan Tinggi (Antara Fungsi dan Estetika), Khizanah al-Hikmah, Vol.1 No.2 Juli- 
Desember 2013, lihat http://journal.uinalauddin.ac.id/index.php/khizanah-al-hikmah/article/view/31/12, diakses tanggal 12 Desember 2018.

https://media.neliti.com/media/publications/15374-ID-desain-interiorperpustakaan-sebagai-sarana-edukasi-dan-hiburan-dengan-konseppo.pdf, diakses tanggal 12 Desember 2018

Kanshin, Kami No, Arsitektur Post Modern dan Postmoderisme , Lihat http://kaminokanshin.blogspot.com/2014/09/post-modern-arsitekturdan-pengertian.html, diakses tanggal 12 Desember 2018.

Noviani, Resti, Rusmana, Agus, dan Rodiah, Saleha, Peranan Desain Interior Perpustakaan dalam Menumbuhkan Minat pada Ruang Perpustakaan, JURNAL KAJIAN INFORMASI \& PERPUSTAKAAN, Vol.2/No.1, Juni 2014, hlm.37-46

Setiawan, Iwan F., Arsitektur Modern, Pengertian Postmodern dan Arsitektur Postmodern, Lihat http://iwanarsitekkidal.blogspot.com/2011/07/arsitektur-modern_8359.html, diakses tanggal 7 Desember 2018

Susanti, Eka dan Budiono, Desain Interior Perpustakaan sebagai Sarana Edukasi dan Hiburan dengan Konsep Post Modern, JURNAL SAINS DAN SENI POMITS Vol. 3, No.1, (2014), lihat

Wahana Arsitektur Indonesia, Arsitektur Post Modern, lihat http://wahanaarsitektur-indonesia.blogspot.com/2011/12/arsitektur-postmodern.html 